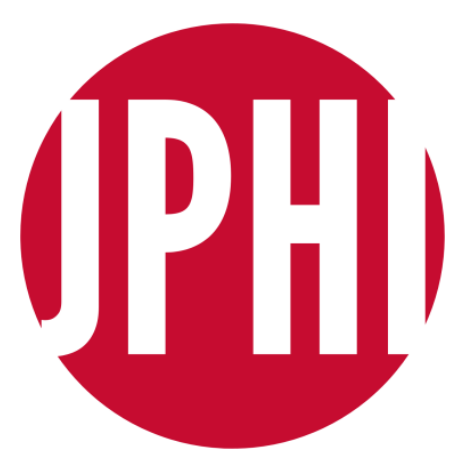

Jurnal Penegakan Hukum Indonesia (JPHI)

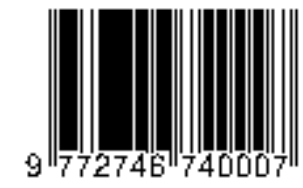

E-ISSN: 2746-7406

\section{HAK CIPTA DANCE CHALLENGE YANG DIUNGGAH KE APLIKASI TIKTOK}

\author{
M. Febry Saputra \\ Fakultas Hukum Universitas Islam Kalimantan \\ Muhammad Arsyad Al-Banjari Banjarmasin \\ Jl. Adhyaksa No. 2 Kayutangi, Banjarmasin, Provinsi \\ Kalimantan Selatan, Indonesia. \\ Email: febrymuhammad89@gmail.com
}

$\begin{array}{ll}\text { Submitted } & : 17 / 12 / 2020 \\ \text { Revised } & : 10 / 01 / 2021 \\ \text { Accepted } & : 12 / 01 / 2021 \\ \text { Published } & : 29 / 01 / 2021\end{array}$

Editorial Office:

Jl. Brigjen H. Hasan Basri Komplek Polsek Banjarmasin Utara Jalur 3, No. 9 Kota Banjarmasin; Provinsi Kalimantan Selatan; Republik Indonesia (70125).

Email

jphi.scholarcenter@gmail.com

Principal Contact +62 82157709493

\section{(C) JPHI 2021}

Licensed under the CC 4.0.

Creative Commons

Attribution-ShareAlike 4.0

International License

\begin{abstract}
The problems studied in this research are to find out, first, how the legal protection system for Dance Challenge video owners uploaded to the TikTok application. Second, how to prove Copyright owner for Dance Challenge video uploaders on the TikTok application. The method used in this paper is the normative legal research, which is literature law research which refers to the legal norms contained in statutory regulations by examining problems using literature either law, doctrine, or books and using the method of statutory approach. The results of the study conclude that users who create Dance Challenge video content on the TikTok application are seen as creators and have been protected as copyright holders for their cinematographic works, adhering to Law Number 28 of 2014 concerning Copyright. If the Dance Challenge video content on the TikTok application is uploaded by another party with the intention of commercial use without the rights and / or permission of the creator or copyright holder, the perpetrator can be charged with criminal penalties as regulated in Law Number 28 of 2014 concerning Copyright. There is nothing different in the process, the procedure for filing a copyright infringement lawsuit related to the Dance Challenge video on the TikTok application, whether it has been registered at the Directorate General of Intellectual Property Rights or that has not been registered and resolved through Arbitration or Commercial Court.
\end{abstract}

Keywords: Copyright; Dance Challenge; TikTok;

Abstrak
Permasalahan yang dikaji dalam penelitian ini adalah untuk
mengetahui, pertama, bagaimana sistem perlindungan hukum bagi
pemilik video Dance Challenge yang diunggah ke aplikasi TikTok.
Kedua, bagaimana cara pembuktian pemilik Hak Cipta bagi


pengunggah video Dance Challenge di aplikasi TikTok. Metode yang digunakan dalam tulisan ini adalah metode penelitian normatif (Normative Legal Research), yaitu penelitian hukum kepustakaan yang mengacu pada norma hukum yang terdapat dalam peraturan perundang-undangan dengan cara mengkaji masalah menggunakan literature baik Undang-Undang, doktrin, atau buku dan menggunakan metode pendekatan perundang-undangan (statute approach). Hasil penelitian menyimpulkan bahwa pengguna yang membuat konten video Dance Challenge pada aplikasi TikTok sudah dipandang sebagai Pencipta dan sudah dilindungi sebagai pemegang Hak Cipta atas karya sinematografnya tersebut, dengan berpegang pada UndangUndang Nomor 28 Tahun 2014 Tentang Hak Cipta. Apabila konten video Dance Challenge pada aplikasi TikTok diunggah pihak lain dengan maksud penggunaan secara komersial tanpa hak dan/atau izin pencipta atau pemegang hak cipta maka pelaku dapat dijerat dengan hukuman pidana yang telah diatur dalam Undang-Undang Nomor 28 Tahun 2014 Tentang Hak Cipta. Tidak ada yang berbeda dalam proses, prosedur dalam tata cara mengajukan gugatan pelanggaran Hak Cipta terkait video Dance Challenge pada aplikasi TikTok baik yang sudah dicatatkan di Direktorat Jenderal Hak Kekayaan Intelektual ataupun yang belum dicatatkan dan diselesaikan melalui Arbitrase atau Pengadilan Niaga.

Kata Kunci: Hak Cipta; Dance Challenge; Aplikasi TikTok;

\section{PENDAHULUAN}

Dunia maya memiliki peran besar pada masa pandemi atau karantina dalam mengurangi penyebaran virus COVID-19. Dunia maya (online, daring) menyampaikan pesan lebih cepat, tampil pendek dan tanpa harus bertemu. ${ }^{1}$ Masyarakat banyak berkreasi di dalam dunia maya seperti membuat konten hiburan bahkan hingga menggunakan sosial media sebagai tempat curhat tentang kehidupan sehari-hari. Hal ini seakan-akan membuat sosial media sebagai tempat yang bebas untuk mengekspresikan diri tanpa batasan. Salah Satu platform ${ }^{2}$ yang sangat mendukung hal tersebut ialah aplikasi TikTok.

Aplikasi TikTok, juga dikenal sebagai Douyin (Hanzi: 抖音短视频

; Pinyin: Dǒuyīn duănshipín; artinya "video pendek vibrato"), adalah sebuah jaringan

${ }^{1}$ Lukas S. Ispandriarno, Membaca Media Daring, Mengikuti Media Sosial: Di Mana Etika?, Jurnal Komunikasi, Volume 10, Nomor 1, Oktober 2015, Hal. 23

${ }^{2}$ Kamus Besar Bahasa Indonesia (KBBI), Kamus versi online/ daring (dalam jaringan), platform/ plat'form/ n 1 rencana kerja; program; 2 pernyataan sekelompok orang atau partai tentang prinsip atau kebijakan; 3 tempat yang tinggi; panggung; pentas; mimbar: masalah penciptaan adalah masalah yang dibahas dalam -- ilmu sastra; 4 beranda stasiun: saya lihat beliau keluar dari -- Tugu langsung menuju tempat kendaraannya, https://kbbi.web.id/platform (diakses pada tanggal 27 September 202006.46 WITA) 
sosial dan platform video musik Tiongkok ${ }^{3}$ yang diluncurkan pada September $2016^{4}$ oleh Zhang Yiming, pendiri Toutiao yang dikembangkan oleh Beijing ByteDance Technology. Aplikasi tersebut membolehkan para pemakai untuk membuat video musik pendek mereka sendiri ${ }^{5}$ dengan durasi video berkisar 15 sampai dengan 60 detik. Douyin pun melakukan ekspansi ke berbagai negara dengan mengusung nama baru, yaitu TikTok.

Aplikasi TikTok bukan hanya aplikasi untuk lip-sync namun juga aplikasi yang memberikan special effects, filter yang unik dan menarik serta beragam pilihan suara dan potongan lagu yang dapat dipilih dan digunakan oleh penggunanya dengan mudah dengan dukungan dari perusahaan teknologi kecerdasan ByteDance sehingga dapat membuat video pendek sehingga penggunanya dapat melakukan performanya dengan tarian, gaya bebas, dan masih banyak lagi sehingga mendorong kreativitas penggunanya menjadi content creatore. Aplikasi Tiktok juga bisa menjadi akun pengembangan bisnis atau pribadi yang berbagi kiat yang tepat dan dapat ditindaklanjuti. ${ }^{6}$ Melalui kontes, tantangan, dan hashtag lokal, aplikasi ini berfokus pada tren lokal yang disukai pengguna.

Menurut catatan Sensor Tower, aplikasi TikTok memiliki 500 juta pengguna aktif di seluruh dunia. Dimana disumbang dari pengguna di negara asalnya sendiri, yakni China dan sepertiganya disumbang pengguna dari India, $^{7}$ serta berbagai belahan dunia lainnya termasuk Indonesia, dengan kisaran jumlah lebih dari 800 juta pengguna aktif di seluruh dunia. Aplikasi TikTok diluncurkan pada 2016 bisa dikatakan baru seumur jagung, namun pada bulan November 2019, Sensor Towermelaporkan bahwa TikTok telah melampaui 1,5 miliar unduhan aplikasi di

${ }^{3}$ TechNode (dalam bahasa Inggris), https://technode.com/2017/09/14/toutiao-backed-douyinlaunches-competitor-to-musical-ly-tik-tok/ , Toutiao Parent Launches Global Competitor To Musical.Ly (diakses pada tanggal 23 September 2020 pukul 11.44 WITA))

4 Ifeng.com (dalam bahasa Tionghoa)，"抖音是否适合奢侈品牌?", http://tech.ifeng.com/a/20180322/44916520_0.shtml (diakses tanggal 23 September 2020 pukul 11.47 WITA)

${ }_{5}$ Wikipedia, https://id.wikipedia.org/wiki/TikTok (diakses pada tanggal 23 September 2020 pukul 11.39 WITA)

${ }^{6}$ Adhitya Wibawa Putra, Tik Tok - Sosial Media Berbasis Video Yang Sedang Sangat Populer, Gadgetren, https://gadgetren.com/2018/03/16/apa-itu-tik-tok-video-media-sosial/ (diakses pada tanggal 23 September 2020 pukul 11.33 WITA)

7 Himam Miladi, Belum Tahu Apa Itu TikTok? Berikut 10 Fakta Pentingnya, Kompasiana, https://www.kompasiana.com/primata/5e3624dad541df0711281812/belum-tahu-apa-itu-tiktokberikut-10-fakta-pentingnya?page=2 (diakses pada tanggal 23 September 2020 pukul 13.28 WITA) 
seluruh dunia yang belum banyak dilampaui dalam waktu singkat jika dibandingkan dengan aplikasi lainnya hingga sekarang. Dengan kedua hal tersebut membuat Bytedance yang didirikan pada 2012 menjadi startup paling bernilai di dunia dengan valuasi lebih dari $\$ 75.000 .000 .000$ (tujuh puluh lima miliar US dolar). ${ }^{8}$ Aplikasi Tiktok juga digunakan sebagai sarana untuk menghibur diri dari rasa bosan serta menjadi panggung untuk menunjukkan ataupun mengasah bakat-bakat yang ada. ${ }^{9}$

Sekitar tahun 2017 TikTok pun datang ke Indonesia. Sama seperti di negara lain, aplikasi video ini pun mengundang banyak perhatian dari berbagai kalangan. Kala itu, TikTok pun sempat hype $e^{10}$ bagi anak sekolah dan ABG (Anak Baru Gede) sebagai tempat pertemuan untuk mereka yang berusia di bawah 25 tahun. Akan tetapi, pada Juli 2018, pemerintah Indonesia pun sempat memblokir TikTok dengan alasan pemblokiran karena aplikasi ini dinilai banyak mengandung konten yang negatif dan tidak mendidik. Namun dalam waktu seminggu, aplikasi TikTok pun sudah beredar lagi di App Store dan Google Play Store. Dengan ketentuan telah adanya kerja sama antara pihak aplikasi TikTok dengan Kementerian Pemberdayaan Perempuan dan Perlindungan Anak di Indonesia.

Faktanya, TikTok adalah aplikasi untuk Generasi Z (Gen Z), ${ }^{11}$ untuk anak-anak remaja masa kini. Dibandingkan dengan platform media sosial lainnya, TikTok

${ }^{8}$ Sam Byford, TikTok owner Bytedance is now the world's most valuable startup, The Verge, https://www.theverge.com/2018/10/26/18026250/bytedance-china-tiktok-valuation-highest-toutiao (diakses pada tanggal 23 September 2020 pukul 21.18 WITA)

${ }^{9}$ Sobih AW Adnan, Mengapa Tiktok Makin Digemari? Ini Alasan dan Dampaknya Secara Psikologis, Oase.id (Rubrik Inspirasi-Psikologi Remaja yang diampu oleh Muharini Aulia-Psikolog Remaja), https://m.oase.id/read/Iw4MP3-mengapa-tiktok-makin-digemari-ini-alasan-dan-dampaknyasecara-psikologis (diakses pada tanggal 25 September 2020 pukul 16.03 WITA)

${ }^{10}$ Brainly, Pengertian hype adalah sebuah kata yang berasal dari bahasa inggris yang berarti sangat senang atau sangat menantikan sesuatu pada sebuah hal secara spesifik, Selain berarti sangat senang. Hype juga berarti sebagai sebuah kegiatan dari pemasaran yang dilakukan oleh perusahaan besar sebagai sebuah strategi pasar ke dalam sebuah bentuk pemasaran dari sebuah produk untuk dapat dianggap menjadi sangatlah menarik dan besar, yang dimana kemudian akan dapat melakukan peningkatan dari pembeli untuk dapat meningkatkan jumlah pembeli untuk menantikan sebuah produk dikarenakan dengan penggunaan kata hype akan menjadi brang yang memiliki harga jual untuk menjadi lebih tinggi. Selain itu juga digunakan pada sebuah hal yang mengejutkan dari kegiatan konser dari seniman yang tidak terduga, https://brainly.co.id/tugas/15603735 (diakses pada tanggal 27 September 2020 pukul 18.06 WITA)

${ }^{11}$ Wikipedia bahasa Indonesia, Ensiklopedia Bebas, dengan rujukan dari Audrey Homan, $Z$ is for Generation Z, Who are Generation Z?, Innovation: Education (dalam bahasa Inggris), Innovative Education in VT, dirilis pada tanggal 27 Oktober 2015, https://tiie.w3.uvm.edu/blog/who-aregeneration-Z/\#.X2_GIGgzbZb, Generasi Z merupakan generasi setelah Generasi Y, yang didefenisikan sebagai orang-orang yang lahir dalam rentang tahun kelahiran 1998 sampai 2010, https://id.wikipedia.org/wiki/Generasi_Z (diakses pada tanggal 23 September 2020 pukul 07.04 WITA) 
memiliki basis pengguna termuda. Hampir 70 persen pengguna TikTok berusia antara 16 hingga 24 tahun, yang berarti bahwa hanya 30 persen berusia 25 tahun ke atas. Dari perspektif pasar, aplikasi yang berfokus pada video pendek lebih menarik perhatian pengguna karena tidak memakan banyak waktu. Pengguna bisa langsung mengidentifikasi konten pilihan dan beralih ke video lainnya jika tidak tertarik. ${ }^{12}$

TikTok mengampanyekan program Challenge, yaitu sebuah program yang berisi tantangan yang bisa dilakukan bersama teman atau pun sendiri. Dengan tujuan orang tersebut untuk menantang orang lain melakukan challenge, salah satunya adalah Dance Challenge. Dimana dalam Dance Challenge tersebut si pemilik akun akan membuat gerakan atau tarian sesuai dengan sound yang telah ada ataupun sound yang baru di aplikasi TikTok untuk diikuti pemilik akun-akun lainnya dari berbagai kalangan penjuru dunia.

Biasanya konten yang paling menarik perhatian pengguna adalah konten tarian (dance content) yang berisi tentang gerakan tarian yang diikuti oleh sound atau tracklist lagu di aplikasi TikTok, konten tarian (dance content) akan dibuat sebuah tantangan (dance chalenge) yang dibuat berdasarkan beberapa track lagu, mulai dari lagu yang aneh (misalnya lagu remix) sampai lagu yang sedang populer baik lagu Indonesia ataupun lagu Barat sekalipun. ${ }^{13}$ Konten tarian (dance content) yang berisi tentang video Dance Challenge adalah aksi menari atau membuat gerakan tertentu sebagai ekspresi terhadap musik yang mengiringinya. Dance Challenge adalah konten di mana mereka akan menari menggunakan koreografi. ${ }^{14}$

Terkait dengan dance challenge maka menarik untuk dikaji dalam pandangan hukum mengenai hal-hal yang berkaitan dengan hal cipta, seperti perlindungan bagi pemilik video serta cara kepemilikan dan upaya yang bisa dilakukan sehingga penting untuk dikaji dalam sebuah karya ilmiah.

12 User, Ini Asal Muasal TikTok yang Kini Mendunia, Kumparan, https://kumparan.com/beritahari-ini/ini-asal-muasal-tiktok-yang-kini-mendunia-1ss18QadAEN/full (diakses pada tanggal 23 September 2020 pukul 22.03 WITA)

13 Editor, 12 Lagu yang Dipakai untuk Video Tik Tok Viral, Ikutan Bikin Jangan?, Axe.com, https://www.axe.com/id/inspirasi/culture/lagu-video-tik-tok-viral.html (diakses pada tanggal 25 September 2020 pukul 16.46 WITA)

${ }^{14}$ Nabila Azarine, Mendunia, ini 7 "lagu tiktok" yang viral karena tren challenge!, Filemagz.com, https://www.filemagz.com/lagu-tiktok-yang-viral/ (diakses pada tanggal 25 September 25, 2020 pukul 16.23 WITA) 


\section{RUMUSAN MASALAH}

Dari deskripsi latar belakang diatas, maka penulis merumuskan beberapa rumusan masalah sebagai berikut:

1. Bagaimana sistem perlindungan hukum bagi pemilik video Dance Challenge yang diunggah ke aplikasi TikTok?

2. Bagaimana cara pembuktian pemilik Hak Cipta bagi pengunggah video Dance Challenge di aplikasi TikTok?

\section{METODE PENELITIAN}

Dalam pembuatan sebuah karya ilmiah terutama karya ilmiah penelitian hukum diharuskan menggunakan metode penelitian hukum. Ilmu hukum berusaha untuk menampilkan hukum secara integral sesuai dengan kebutuhan kajian ilmu hukum itu sendiri, sehingga metode penelitian dibutuhkan untuk memperoleh arah penelitian yang komprehensif. ${ }^{15}$ Penelitian ilmu hukum merupakan kajian itu adalah tentang permasalahan pada penerapan hukum, proses hukum, peristiwa hukum, dan ketentuan peraturan hukum itu sendiri baik secara substansi maupun prosedural. ${ }^{16}$ Sebenarnya ilmu hukum mempunyai ciri-ciri sebagai ilmu yang bersifat preskriptif dan terapan. Dalam preskriptif, ilmu hukum mempelajari tujuan hukum, nilai-nilai keadilan dalam suatu hukum, baik buruk suatu aturan hukum, konsep-konsep dan norma hukum. sedangkan dalam ilmu terapan, ilmu hukum menetapkan suatu prosedur, ketentuan-ketentuan dan batasan-batasan dalam menegakan suatu aturan hukum. ${ }^{17}$

Berdasarkan permasalahan yang akan dikaji diatas maka tipe penelitian yang sesuai untuk melakukan penelitian ini adalah metode penelitian secara yuridis normatif, yakni penelitian yang difokuskan untuk mengkaji penerapan kaidah-kaidah atau norma-norma dalam hukum positif. ${ }^{18}$ Metode penelitian normatif atau penelitian

${ }^{15}$ Yati Nurhayati, "Perdebatan Metode Normatif dengan Metode Empirik Dalam Penelitian Ilmu Hukum Ditinjau Dari Karakter, Fungsi dan Tujuan Ilmu Hukum", Jurnal Al Adl, Volume 5 Npmor 10, 2013. Hal. 15.

${ }^{16}$ Yati Nurhayati, Ifrani, \& M. Yasir Said, (2021), Metodologi Normatif dan Empiris Dalam Perspektif Ilmu Hukum, Jurnal Penegakan Hukum Indonesia, Vol. 2, No.1, Tahun 2021, hlm.1-20

${ }^{17}$ Yati Nurhayati, Pengantar I/mu Hukum, Nusa Media, Bandung, 2020. Hal. 9. Hal. 141

${ }_{18}$ Peter Mahmud Marzuki, Penelitian Hukum, Jakarta, Kencana Prenada Media Group, 2011, 
hukum doktrinal bertujuan untuk menemukan jawaban-jawaban yang benar dengan melakukan pembuktian kebenaran yang dicari dari preskripsi-preskripsi hukum yang tertulis dalam kitab Undang-Undang hukum positif atau kitab-kitab agama. ${ }^{19}$

\section{PEMBAHASAN}

\section{Sistem Perlindungan Hukum Bagi Pemilik Unggahan Video Dance Challenge Ke Aplikasi TikTok}

Menurut Satjipto Raharjo mendefinisikan perlindungan hukum adalah memberikan pengayoman kepada hak asasi manusia yang dirugikan orang lain dan perlindungan tersebut diberikan kepada masyarakat agar mereka dapat menikmati semua hak-hak yang diberikan oleh hukum. ${ }^{20}$ Menurut Muchsin, perlindungan hukum merupakan kegiatan untuk melindungi individu dengan menyerasikan hubungan nilai-nilai atau kaidah-kaidah yang menjelma dalam sikap dan tindakan dalam menciptakan adanya ketertiban dalam pergaulan hidup antar sesama manusia. ${ }^{21}$ Sedangkan menurut Setiono, perlindungan hukum adalah tindakan atau upaya untuk melindungi masyarakat dari perbuatan sewenang-wenang oleh penguasa yang tidak sesuai dengan aturan hukum, untuk mewujudkan ketertiban dan ketentraman sehingga memungkinkan manusia untuk menikmati martabatnya sebagai manusia. ${ }^{22}$

Hak Cipta atau biasa dikenal dan disebut dengan Copyright pasti diiringi dengan adanya pembuatan sebuah karya yang bernilai kreatif dapat berupa sastra, seni, pendidikan, atau bentuk musik yang termasuk ke dalam jenis kekayaan intelektual yang memberikan hak eksklusif kepada pemiliknya untuk membuat salinan dari suatu karya kreatif, biasanya untuk waktu yang terbatas. Hak cipta dimaksudkan untuk melindungi ekspresi asli dari suatu ide dalam bentuk karya kreatif, tetapi bukan ide itu sendiri.

Aturan mengenai hak cipta terdapat dalam Undang-Undang Nomor 28 Tahun 2014 tentang Hak Cipta (selanjutnya disebut dengan UU Hak Cipta). Menurut Pasal 1 angka 1 UU Hak Cipta, hak cipta yaitu hak eksklusif pencipta yang timbul secara

${ }^{19}$ Soetandyo Wignjosoebroto dalam Sulistyowati Irianto dan Shidarta (ed.), Metode Penelitian Hukum; Konstelasi dan Refleksi, Yayasan Pustaka Obor Indonesia, Jakarta, 2017, Hal. 121

${ }^{20}$ Satjipto Rahardjo, IImu Hukum, Citra Aditya Bakti, Bandung, Cetakan ke-V, 2000, Hal. 53.

${ }^{21}$ Muchsin, Perlindungan dan Kepastian Hukum bagi Investor di Indonesia, Surakarta, Magister Ilmu Hukum Program Pascasarjana Universitas Sebelas Maret, 2003, Hal. 14

${ }^{22}$ Setiono, Rule of Law (Supremasi Hukum), Magister Ilmu Hukum Program Pascasarjana Universitas Sebelas Maret, Surakarta, 2004, Hal. 3. 
otomatis berdasarkan prinsip deklaratif setelah suatu ciptaan diwujudkan dalam bentuk nyata tanpa mengurangi pembatasan sesuai dengan ketentuan peraturan perundang-undangan.

Meskipun menurut hukum hak cipta diperoleh secara otomtis ketika suatu ciptaan lahir atau diwujudkan dalam sebuah bentuk nyata, namun apabila terhadap ciptaan tersebut dilakukan pencatatan dan pendaftaran melalui prosedur hukum maka akan lebih baik dan lebih menguntungkan, karena dengan pencatatan didapat bukti formal. ${ }^{23}$ Salah satu ciptaan yang dilindungi adalah karya sinematografi, yaitu: ${ }^{24}$ Ciptaan yang berupa gambar bergerak (moving images) antara lain film dokumenter, film iklan, reportase atau film cerita yang dibuat dengan skenario, dan film kartun. Karya sinematografi dapat dibuat dalam pita seluloid, pita video, piringan video, cakram optik dan/atau media lain yang memungkinkan untuk dipertunjukkan di bioskop, layar lebar, televisi, atau media lainnya. Sinematografi merupakan salah satu contoh bentuk audiovisual. Sehingga, konten video TikTok dapat dikategorikan sebagai suatu bentuk karya sinematografi yang dilindungi hak cipta.

Perlindungan hak cipta atas karya sinematografi berdasarkan UU Hak Cipta berlaku selama 50 tahun sejak pertama kali dilakukan pengumuman, yakni pembacaan, penyiaran, pameran, suatu ciptaan dengan menggunakan alat apapun baik elektronik atau non elektronik atau melakukan dengan cara apapun sehingga suatu ciptaan dapat dibaca, didengar, atau dilihat orang lain.

Dari laman TikTok pada bagian Ketentuan Layanan, seluruh konten, perangkat lunak, gambar, teks, karya grafis, ilustrasi, logo, hak paten, merek dagang, merek jasa, hak cipta, foto, audio, video, musik, dan seluruh hak atas kekayaan intelektual yang terkait dengan Layanan (Konten TikTok), adalah dimiliki atau diberikan lisensi oleh TikTok, karena perlu dipahami bahwa Anda atau pemberi lisensi Anda akan memiliki setiap Konten Pengguna yang diunggah atau dikirimkan melalui Layanan.

Hubungan hukum antara pengguna aplikasi Tiktok dengan pemegang Hak Cipta adalah sebagai perjanjian hubungan kerjasama seperti yang tertuang pada Perjanjian Konten Buatan Pengguna (User Generated Content), dikarenakan pengguna aplikasi Tiktok tersebut sebelumnya diberikan kebebasan yang bebas oleh

${ }^{23}$ Hasrina Rahma dan Yati Nurhayati, Legalitas Cover Song Yang Diunggah ke Akun Youtube, Jurnal A/ Adl Volume 12 Nomor 1 Januari 2020. Hal. 85.

${ }^{24}$ Lihat pada Pasal 40 huruf $\mathrm{m}$ Undang-Undang Nomor 28 Tahun 2014 Tentang Hak Cipta 
pihak aplikasi Tiktok untuk menggunakan lagu atau konten yang diunggah sendiri pada aplikasi Tiktok dengan syarat sudah mendapatkan ijin terlebih dahulu kepada pemegang Hak Cipta. ${ }^{25}$

Dari penjelasan di atas dapat diambil kesimpulan bahwa gerakan yang diciptakan dalam video Dance Challenge merupakan salah satu unsur karya seni dalam jenis karya sinematograpi berupa video dalam aplikasi TikTok. Unsur yang terdapat dalam video Dance Challenge tersebut merupakan salah satu ciptaan yang dilindungi oleh UU Hak Cipta dan termasuk kedalam karya sinematografi. ${ }^{26}$

Ciptaan adalah setiap hasil karya cipta di bidang ilmu pengetahuan, seni, dan sastra yang dihasilkan atas inspirasi, kemampuan, pikiran, imajinasi, kecekatan, keterampilan, atau keahlian yang diekspresikan dalam bentuk nyata. ${ }^{27}$ Bagi pemilik akun yang memiliki video Dance Challenge bisa dikatakan sebagai pencipta dari gerakan dalam video Dance Challenge tersebut dengan ketentuan: ${ }^{28}$

Kecuali terbukti sebaliknya, yang dianggap sebagai Pencipta, yaitu Orang yang namanya:

a. disebut dalam Ciptaan;

b. dinyatakan sebagai Pencipta pada suatu Ciptaan;

c. disebutkan dalam surat pencatatan Ciptaan; dan/atau

d. tercantum dalam daftar umum Ciptaan sebagai Pencipta.

Pelindungan Hak Cipta tidak menyaratkan pencatatan sebagai bukti atas lahirnya hak eksklusif pencipta terhadap ciptaannya, dengan penjelasan sebagai berikut: ${ }^{29}$ Hak Cipta adalah hak eksklusif pencipta yang timbul secara otomatis berdasarkan prinsip deklaratif setelah suatu ciptaan diwujudkan dalam bentuk nyata tanpa mengurangi pembatasan sesuai dengan ketentuan peraturan perundangundangan.

${ }^{25}$ Revian Tri Pamungkas, Djulaeka, Perlindungan Hukum Pemegang Hak Cipta Atas Lagu yang Diunggah Pada Aplikasi Tiktok, Simposium Hukum Indonesia, Dipublikasikan oleh Fakultas Hukum Universitas Trunojoyo Madura, dapat diakses secara online pada http://journal.trunojoyo.ac.id/shi , Volume 1, Nomor 1, 2019, Hal.411

${ }^{26}$ Lihat pada Pasal 40 ayat (1) huruf m Undang-Undang Nomor 28 Tahun 2014 tentang Hak Cipta, Yang dimaksud dengan "karya sinematografi" adalah Ciptaan yang berupa gambar bergerak (moving images) antara lain film dokumenter, film iklan, reportase atau film cerita yang dibuat dengan skenario, dan film kartun. Karya sinematografi dapat dibuat dalam pita seluloid, pita video, piringan video, cakram optik dan/atau media lain yang memungkinkan untuk dipertunjukkan di bioskop, layar lebar, televisi, atau media lainnya. Sinematografi merupakan salah satu contoh bentuk audiovisual.

${ }^{27}$ Lihat pada Pasal 1 angka 3 Undang-Undang Nomor 28 Tahun 2014 tentang Hak Cipta

${ }^{28}$ Lihat pada Pasal 31 Undang-Undang Nomor 28 Tahun 2014 Tentang Hak Cipta

${ }^{29}$ Lihat pada Pasal 1 Angka 1 Undang-Undang Nomor 28 Tahun 2014 Tentang Hak Cipta 
Perlindungan Hukum terhadap hasil karya cipta menganut sistem perlindungan otomatis (automatic protection) artinya diperoleh pencipta secara otomatis, tanpa melalui proses pencatatan terlebih dahulu pencipta secara otomatis sudah mendapat perlindungan hukum atas karya cipta nya saat karya tersebut sudah diwujudkan dalam bentuk karya cipta nyata (expression work). ${ }^{30}$ Lebih lanjut dijelaskan bahwa UU Hak Cipta menganut asas first to use. Akan tetapi bentuk karya itu harus dibuat dalam bentuk nyata (bukan sekedar ide) yang kemudian dipublikasikan. ${ }^{31}$

Meskipun menurut hukum Hak Cipta perlindungan bersifat otomatis yang diperoleh oleh pencipta sejak ciptaan diwujudkan dalam bentuk nyata, dan tidak harus melalui proses pencatatan, namun apabila dilakukan pencatatan akan lebih baik dan lebih menguntungkan, karena dengan pencatatan, akan ada bukti formal adanya Hak Cipta jika tidak terbukti sebaliknya. Dengan adanya proses pencatatan jika terjadi peniruan atau penjiplakan karya cipta, si pencipta lebih mudah membuktikan haknya dan mengajukan tuntutan, karena ada bukti formal pencatatan. ${ }^{32}$

Perlindungan Hak Cipta atas ciptaan berupa karya sinematografi berlaku selama 50 (lima puluh) tahun sejak pertama kali dilakukan pengumuman. ${ }^{33}$ Pengumuman adalah pembacaan, penyiaran, pameran, suatu ciptaan dengan menggunakan alat apapun baik elektronik atau non elektronik atau melakukan dengan cara apapun sehingga suatu ciptaan dapat dibaca, didengar, atau dilihat orang lain. ${ }^{34}$ Jadi video yang berisi tentang gerakan Dance Challenge pada aplikasi TikTok (sebagai bentuk karya sinematografi) pada dasarnya sudah dilindungi oleh Hak Cipta sejak pertama kali dilakukan pengumuman karena perlindungan terhadap

${ }^{30}$ Ni Ketut Supasti Dharmawan, dkk, Hak Kekayaan Intelektual, Yogyakarta, Deepublish, 2016, Hal. 38- 39

${ }^{31}$ Yati Nurhayati, Ifrani, Abdul Halim Barkatullah, dan M. Yasir Said, The Issue of Copyright Infringement in 4.0 Industrial Revolution: Indonesian Case, Jurnal Media Hukum, Vol. 26 No. 2, December, 2019, Hal. 124

32 Ibid. Cipta

${ }^{33}$ Lihat pada Pasal 59 ayat (1) huruf c Undang-Undang Nomor 28 Tahun 2014 Tentang Hak

${ }^{34}$ Lihat pada Pasal 1 angka 11 Undang-Undang Nomor 28 Tahun 2014 Tentang Hak Cipta 
ciptaan tersebut lahir secara otomatis berdasarkan prinsip deklaratif setelah suatu ciptaan diwujudkan dalam bentuk nyata. ${ }^{35}$

\section{Cara Pembuktian Pemilik Hak Cipta Untuk Pengunggah Video Dance Challenge Di Aplikasi Tiktok.}

Dalam hal pengunggahan video yang berisi gerakan Dance Challenge pada aplikasi TikTok termasuk kedalam Asas Deklaratif (first to file) yang secara otomatis mendapatkan Hak Cipta atas pembuatan gerakan dalam video Dance Challenge di aplikasi TikTok karena ketika video Dance Challenge tersebut telah diunggah ke akun pengguna TikTok maka secara otomatis akan terlihat waktu pengunggahan video tersebut, dalam bentuk tanggal-bulan-tahun yang mana hal itu menjadi bukti nyata sebuah video kapan pertama kali diunggah atau diposting di aplikasi TikTok. Penyebutan waktu pada unggahan video Dance Challenge menjadi daya pembeda antara video Dance Challenge yang lain sebagai status siapa pengunggah pertama video Dance Challenge tersebut, dan biasanya jika ada yang mengikuti gerakan dalam video Dance Challenge tersebut dan menggunakan sound yang sama dengan peunggah pertama, maka posisi si pengunggah pertama akan berada dibagian paling atas dan ada embel-embel origina/dibagian videonya.

Dengan menggunakan asas deklaratif (first to file) berdasarkan waktu (tanggal-bulan-tahun) yang tertera didalam video Dance Challenge menjadi bukti kuat bahwa benar pemilik akun TikTok yang bersangkutan memang pengunggah pertama dan/ atau pembuat gerakan video Dance Challenge pertama yang mana secara otomatis telah mendapat Hak Cipta walaupun tanpa pendaftaran ke DJHKI.

Dalam hal ada yang mengklaim bahwa karya berupa gerakan dalam video Dance Challenge pihak TikTok memiliki hak untuk mengungkapkan identitas Anda kepada pihak ketiga manapun yang mengklaim bahwa setiap Konten Pengguna yang dimuat atau diunggah oleh Anda ke Layanan kami merupakan pelanggaran terhadap

${ }^{35}$ Lihat pada Pasal 1 angka 1 Undang-Undang Nomor 28 Tahun 2014 Tentang Hak Cipta. Lihat juga Yati Nurhayati dan Ifrani, Judicial Review Of Shifted Offense in Copyright Law 28/2014, Jurnal Pembaharuan Hukum, Volume VI Nomor 3 September-Desember 2019. Hal. 373. 
hak atas kekayaan intelektual pihak ketiga tersebut, atau terhadap hak privasi mereka. ${ }^{36}$

Dalam hal pembuktian siapa yang lebih dahulu membuat, menggunakan dan/atau mendokumentasikan hasil karya berupa Dance Challenge bisa dilihat dan membandingkan dari kapan waktu (berupa tanggal-bulan-tahun) kedua dan/atau beberapa video Dance Challenge yang menggunakan gerakan dan/atau sound yang sama. Dari tolak ukur waktu, bisa dibuktikan siapa yang menjadi pionir dalam mempublikasikan Dance Challenge tersebut di akun pengguna TikTok yang bersangkutan.

Pihak TikTok memiliki hak untuk mengungkapkan identitas Anda kepada pihak ketiga manapun yang mengklaim bahwa setiap Konten Pengguna yang dimuat atau diunggah oleh Anda ke Layanan kami merupakan pelanggaran terhadap hak atas kekayaan intelektual pihak ketiga tersebut, atau terhadap hak privasi mereka. ${ }^{37}$ Terkait Konten Video,Aplikasi TikTok mengizinkan penggunanya untuk membuat dan mengunggah video. Video tersebut dapat disimpan secara pribadi (Video Pribadı) atau diposting di aplikasi TikTok dan dapat ditonton oleh pengguna terdaftar (Video Publik). Kecuali sebuah akun telah diatur ke setelan pribadi atau Video Publik telah dihapus oleh pengguna, Video Publik dapat ditonton oleh penegak hukum melalui aplikasi TikTok dan oleh karena itu, tidak diberikan melalui Permohonan Data. Informasi ini hanya akan tersedia berdasarkan surat perintah penggeledahan. ${ }^{38}$

Jika video Dance Challenge tersebut dimiliki akun pengguna aplikasi TikTok yang bersifat "Publik" bukan akun "Pribadi" dan video Dance Challenge bersifat sebagai "Video Publik" maka akan sangat mudah bagi penegak hukum untuk melihat secara langsung semua keterangan dari video tersebut, baik dari nama pemilik atau pengguna TikTok, Judul dari video yang tertera, apakah memuat credit; inspired by; duet with dan/atau react dari muatan milik orang lain yang terkandung dalam video

${ }^{36}$ Situs resmi TikTok, Ketentuan Umum - Seluruh Pengguna (terakhir diperbarui: Februari 2020), https://www.tiktok.com/legal/terms-of-use?lang=id (diakses pada tanggal 24 September 2020 pukul 00.20 WITA)

37 Situs resmi TikTok, Ketentuan Umum - Seluruh Pengguna (terakhir diperbarui: Februari 2020), https://www.tiktok.com/legal/terms-of-use?lang=id (diakses pada tanggal 24 September 2020 pukul 00.20 WITA)

38 Situs resmi TikTok, Penegakan Hukum (terakhir diperbaharui: 13 Agustus 2020), https://www.tiktok.com/legal/law-enforcement?lang=id (diakses pada tanggal 24 September 2020 pukul 00.42 WITA) 
Dance Challenge tersebut, apakah sound yang digunakan sama dengan milik orang lain dan yang paling terpenting dari video Dance Challenge yang bersifat Video Publik bisa secara jelas terlihat kapan video Dance Challenge itu dipublikasikan atau diposting di akun pengguna. Beda hal dengan video Dance Challenge yang sifatnya Video Private / Video Pribadi maka harus ada prosedur lain yang harus dilakukan untuk bisa meng-akses keseluruhan video tersebut, baik dengan izin secara langsung kepada pemilik akun dan/atau melakukan konfirmasi langsung ke pihak TikTok sesuai dengan yang tertera dalam Ketentuan Pengguna bagian Penegakan Hukum. ${ }^{39}$

Keabsahan Hak Cipta dari gerakan dalam video Dance Challenge akan secara tidak langsung menimbulkan Hak Eks/usif ${ }^{40}$ bagi pemilik akun TikTok, berupa:

Dari sisi Hak Mora/ untuk melakukan:

a. tetap mencantumkan atau tidak mencantumkan namanya pada salinan sehubungan dengan pemakaian ciptaannya untuk umum;

b. menggunakan nama aliasnya atau samarannya;

c. mengubah ciptaannya sesuai dengan kepatutan dalam masyarakat;

d. mengubah judul dan anak judul ciptaan; dan

e. mempertahankan haknya dalam hal terjadi distorsi ciptaan, mutilasi ciptaan, modifikasi ciptaan, atau hal yang bersifat merugikan kehormatan diri atau reputasinya. ${ }^{41}$

Adapun Hak Ekonomi yang didapat dari pencipta gerakan dalam video Dance Challenge, untuk melakukan berupa: ${ }^{42}$

a. penerbitan ciptaan;

b. penggandaan ciptaan dalam segala bentuknya;

c. penerjemahan ciptaan;

d. pengadaptasian, pengaransemenan, atau pentransformasian ciptaan;

e. pendistribusian ciptaan atau salinannya;

f. pertunjukan ciptaan;

g. pengumuman ciptaan;

h. komunikasi ciptaan; dan

39 Situs resmi TikTok, Penegakan Hukum (terakhir diperbaharui: 13 Agustus 2020), https://www.tiktok.com/legal/law-enforcement?lang=id, Kebijakan Tiktok Untuk Menanggapi Permohonan Penegak Hukum, TikTok berkomitmen untuk membantu penegak hukum dengan tetap menghormati privasi dan hak penggunanya. Untuk memperoleh informasi pengguna yang bersifat non-publik, penegak hukum harus menyerahkan dokumen hukum yang sesuai yang diperlukan untuk jenis informasi yang dicari, seperti surat perintah pengadilan atau surat perintah penggeledahan (diakses pada tanggal 24 September 202010.33 WITA)

40 Lihat pada Pasal 4 Undang-Undang Nomor 28 Tahun 2014 Tentang Hak Cipta, yang dimaksud dengan Hak Ekslusif terdiri atas Hak Moral dan Hak Ekonomi

${ }^{41}$ Lihat pada Pasal 5 ayat (1) Undang-Undang Nomor 28 Tahun 2014 Tentang Hak Cipta, yang dimaksud dengan Hak Moral merupakan hak yang melekat secara abadi pada diri Pencipta

${ }^{42}$ Lihat pada Pasal 9 Ayat (1) Undang-Undang Nomor 28 Tahun 2014 Tentang Hak Cipta 
i. penyewaan ciptaan.

Namun perlu diingat bahwa Hak Ekonomi tidak bisa dituntut karena tujuan awal pembuatan gerakan dalam video Dance Challenge tersebut hanya untuk publikasi hiburan semata bukan untuk tujuan penggunaan secara komersial. ${ }^{43}$ Terkecuali jika memang pada tujuan awal pembuatan video yang mengandung gerakan Dance Challenge diperuntukan untuk penggunaan secara komersial dan/ atau ada yang ingin mengkomersialkannya maka setiap orang yang hendak dan/ atau akan melaksanakan hak ekonomi wajib mendapatkan izin pencipta atau pemegang Hak Cipta yaitu si pembuat gerakan di video Dance Challenge (dalam hal ini pemilik akun di aplikasi TikTok). Kemudian setiap orang dilarang tanpa izin pencipta atau pemegang Hak Cipta melakukan penggandaan dan/atau penggunaan secara komersial ciptaan. ${ }^{44}$

\section{Upaya Hukum Terhadap Pelanggaran Hak Cipta Video Dance Challenge Di Aplikasi TikTok}

Tiada larangan dalam menggunakan gerakan dalam video Dance Challenge milik orang lain dan diunggah ke akun TikTok masing-masing, karena sifat dari video tersebut berupa tantangan (challenge) yang secara otomatis diperuntukan untuk diikuti oleh orang lain ditambah lagi video Dance Challenge itu dibuat untuk video yang sifatnya publik dan tidak ada tujuan untuk penggunaan komersial baik sebelum pembuatan atau setelah pembuatannya. Di satu sisi, hal ini tentu membuat sangat mudah bagi hampir semua orang untuk melanggar Hak Cipta orang lain dalam skala yang sangat besar, tetapi di sisi lain sangat sulit bagi pemilik Hak Cipta untuk mengetahui terjadinya pelanggaran, mengenali, atau pun kemudian melakukan upaya hukum. ${ }^{45}$

${ }^{43}$ Lihat pada Penjelasan Pasal 55 Ayat (1) Undang-Undang Nomor 28 Tahun 2014 Tentang Hak Cipta, Yang dimaksud dengan "penggunaan secara komersial" dalam media teknologi informasi dan komunikasi mencakup penggunaan komersial secara langsung (berbayar) maupun penyediaan layanan konten gratis yang memperoleh keuntungan ekonomi dari pihak lain yang mengambil manfaat dari penggunaan Hak Cipta dan/atau hak terkait dimaksud.

${ }^{44}$ Lihat pada Pasal 9 Ayat (2) dan (3) Undang-Undang Nomor 28 Tahun 2014 Tentang Hak Cipta

${ }^{45}$ Isnaini, Yusran, Hak Cipta dan Tantangannya di Era Cyber Space, Ghalia Indonesia, Bogor, 2009, Hal. 28 
Pemilik Konten Pengguna masih memiliki Hak Cipta dalam Konten Pengguna yang dikirimkan, namun dengan mengirimkan Konten Pengguna melalui Layanan, dengan ini memberikan kepada TikTok lisensi yang bersifat tanpa syarat dan tidak dapat ditarik kembali, non-eksklusif, bebas royalti. Lisensi itu dapat dialihkan secara penuh dan tidak terbatas secara global untuk menggunakan, memodifikasi, menyesuaikan, mereproduksi, membuat karya-karya turunan, mengumumkan dan/atau mengirimkan, dan/atau mendistribusikan dan memberikan wewenang kepada para pengguna Layanan lainnya dan para pihak ketiga untuk melihat, mengakses, menggunakan, mengunduh, memodifikasi, menyesuaikan, mereproduksi, membuat karya-karya turunan dari, mempublikasikan dan/atau mengirimkan konten dalam format dan platform apapun.

Sesuai dengan aturan pengguna yang telah ada dalam aplikasi TikTok, disebutkan bahwa: ${ }^{46}$ Pihak TikTok memiliki hak untuk mengungkapkan identitas Anda kepada pihak ketiga manapun yang mengklaim bahwa setiap Konten Pengguna yang dimuat atau diunggah oleh Anda ke Layanan kami merupakan pelanggaran terhadap hak atas kekayaan intelektual pihak ketiga tersebut, atau terhadap hak privasi mereka.

Jadi, jika terjadi pengakuan atau pelanggaran atas Hak Cipta pemilik gerakan dalam video Dance Challenge maka pihak aplikasi TikTok mempunyai hak untuk memberikan informasi data pemilik akun yang telah melanggar Hak Cipta kepada pihak lain baik kepada pemilik akun TikTok yang telah dilanggar Hak Cipta-nya ataupun diberikan kepada pihak berwajib atau penegak hukum. TikTok mempunyai lisensi sendiri di dalamnya dan dalam ketentuan Undang-Undang yang berlaku disebutkan bahwa: "perjanjian lisensi dilarang menjadi sarana untuk menghilangkan atau mengambil alih seluruh hak pencipta atas ciptaannya. ${ }^{\text {A7 }}$

Setiap orang dilarang tanpa izin pencipta atau pemegang Hak Cipta melaksanakan hak ekonomi serta melakukan penggandaan dan/atau penggunaan secara komersial ciptaan. ${ }^{48}$ Hak ekonomi yang melekat pada pencipta atau

${ }^{46}$ Situs resmi TikTok, Ketentuan Umum - Seluruh Pengguna (terakhir diperbarui: Februari 2020), https://www.tiktok.com/legal/terms-of-use?lang=id (diakses pada tanggal 24 September 2020 pukul 00.20 WITA)

${ }^{47}$ Lihat pada Pasal 82 Ayat (3) Undang-Undang Nomor 28 Tahun 2014 Tentang Hak Cipta Cipta

${ }^{48}$ Lihat pada Pasal 9 ayat (2) dan (3) Undang-Undang Nomor 28 Tahun 2014 Tentang Hak 
pemegang Hak Cipta tersebut. Perbuatan menyiarkan ulang sebuah film atau video melalui internet dapat dikategorikan sebagai penyiaran $^{49}$ atau pengumuman ${ }^{50}$ ciptaan dalam rangka melaksanakan hak ekonomi maka hal tersebut wajib mendapatkan izin pencipta atau pemegang hak cipta. ${ }^{51}$ Setiap orang yang dengan tanpa hak dan/atau tanpa izin pencipta atau pemegang Hak Cipta melakukan pelanggaran hak ekonomi pencipta sebagaimana dimaksud Pasal 9 ayat (1) huruf $b$, e, dan g UU Hak Cipta untuk penggunaan secara komersial akan menerima sanksi pidana berupa pidana penjara maksimal 4 tahun dan/atau pidana denda maksimal Rp. 1.000 .000 .000 (satu miliar rupiah). ${ }^{52}$

Jadi, apabila konten video Dance Challenge di aplikasi TikTok diunggah dengan maksud penggunaan komersial ke akun pengguna TikTok lain dan/ atau media sosial lainnya atau bahkan menjadi mata acara (program televisi) atau konten program di lembaga penyiaran, maka pelaku dapat dijerat dengan hukuman pidana jika dilakukan tanpa hak dan/atau izin pencipta atau pemegang Hak Cipta. ${ }^{53}$

Namun ada pengecualian dalam hal menggunakan hasil karya orang lain (dalam hal ini gerakan dalam video Dance Challenge di aplikasi TikTok) yang sudah didaftarkan dan dilindungi Hak Cipta tanpa melanggar Hak Cipta pemiliknya, yaitu hanya sebatas meniru atau mengikuti gerakan dan hanya dipublikasikan di akun aplikasi TikTok pribadi tanpa ada tujuan penggunaan secara komersial dan/atau menguntungkan Pencipta atau pihak terkait, atau Pencipta tersebut menyatakan tidak keberatan atas pembuatan dan penyebarluasan tersebut. ${ }^{54}$

49 Lihat pada Pasal Pasal 1 angka 15 Undang-Undang Nomor 28 Tahun 2014 Tentang Hak Cipta, Penyiaran adalah pentransmisian suatu ciptaan atau produk hak terkait tanpa kabel sehingga dapat diterima oleh semua orang di lokasi yang jauh dari tempat transmisi berasal.

${ }^{50}$ Lihat pada Pasal 1 angka 11 Undang-Undang Nomor 28 Tahun 2014 Tentang Hak Cipta, Pengumuman adalah pembacaan, penyiaran, pameran, suatu ciptaan dengan menggunakan alat apapun baik elektronik atau non elektronik atau melakukan dengan cara apapun sehingga suatu ciptaan dapat dibaca, didengar, atau dilihat orang lain. Perbuatan menyiarkan ulang sebuah film atau video melalui internet dapat dikategorikan sebagai penyiaran.

${ }_{51}$ Abi Jam'an Kurnia, S.H., Jerat Pidana Re-Uploader Video di YouTube, Hukum Online, https://www.hukumonline.com/klinik/detail/ulasan/lt597f0045bbbe1/jerat-pidana-ire-uploader-i-videodi-iyoutube (diakses pada tanggal 27 September 2020 pukul 21.57 WITA)

52 Lihat pada Pasal 113 ayat (3) Undang-Undang Nomor 28 Tahun 2014 Tentang Hak Cipta

53 Bernadetha Aurelia Oktavira, S.H., Hukumnya 'Comot' Konten TikTok untuk Medsos atau Program TV, Hukum Online, https://www.hukumonline.com/klinik/detail/ulasan/lt5ece5f360135a/hukumnya-comot-konten-tiktokuntuk-medsos-atau-program-tv/ (diakses pada tanggal 24 September 2020 pukul 22.08 WITA)

${ }^{54}$ Lihat pada Pasal 43 huruf d Undang-Undang Nomor 28 Tahun 2014 tentang Hak Cipta, dijelaskan bahwa pembuatan dan penyebarluasan konten Hak Cipta melalui media teknologi informasi 
TikTok akan memenuhi permohonan resmi dari penegak hukum untuk mengamankan data pengguna. Setelah menerima surat permohonan pengamanan data yang ditandatangani dan diberi tanggal dengan kop surat resmi dari lembaga penegak hukum yang berisi seluruh informasi yang disyaratkan di bawah ini, TikTok akan berupaya untuk mengamankan informasi akun yang ada yang terkait dengan pengguna TikTok yang diidentifikasi dengan patut selama 90 hari.

Jika kedepannya terjadi sengketa (gugat-menggugat) mengenai Hak Cipta mengenai isi dari video Dance Challenge berupa gerakan yang termuat di dalamnya, baik yang sudah didaftarkan sebelumnya ataupun belum didaftarkan ke DJHKI, maka hal itu bisa saja dilakukan oleh para pihak yang bersengketa sesuai dengan proses atau prosedur yang telah ditentukan UU Hak Cipta. Dengan prosedur atau tata cara gugatan pelanggaran Hak Cipta sebagai berikut: ${ }^{55}$

1) Gugatan atas pelanggaran Hak Cipta diajukan kepada ketua Pengadilan Niaga.

2) Gugatan sebagaimana dimaksud pada ayat (1) dicatat oleh panitera Pengadilan Niaga dalam register perkara pengadilan pada tanggal gugatan tersebut didaftarkan.

3) Panitera Pengadilan Niaga memberikan tanda terima yang telah ditandatangani pada tanggal yang sama dengan tanggal pendaftaran.

4) Panitera Pengadilan Niaga menyampaikan permohonan gugatan kepada ketua Pengadilan Niaga dalam waktu paling lama 2 (dua) Hari terhitung sejak tanggal gugatan didaftarkan.

5) Dalam waktu paling lama 3 (tiga) Hari terhitung sejak gugatan didaftarkan, Pengadilan Niaga menetapkan Hari sidang.

6) Pemberitahuan dan pemanggilan para pihak dilakukan oleh juru sita dalam waktu paling lama 7 (tujuh) Hari terhitung sejak gugatan didaftarkan. ${ }^{56}$ berikut: ${ }^{57}$

Dengan ketentuan putusan gugatan pelanggaran Hak Cipta adalah sebagai

1) Putusan atas gugatan harus diucapkan paling lama 90 (sembilan puluh) Hari sejak gugatan didaftarkan.

2) Dalam hal jangka waktu sebagaimana dimaksud pada ayat (1) tidak dapat dipenuhi, atas persetujuan Ketua Mahkamah Agung jangka waktu tersebut dapat diperpanjang selama 30 (tiga puluh) Hari.

3) Putusan sebagaimana dimaksud pada ayat (1) harus diucapkan dalam sidang terbuka untuk umum.

dan komunikasi yang bersifat tidak komersial dan/atau menguntungkan Pencipta atau pihak terkait, atau Pencipta tersebut menyatakan tidak keberatan atas pembuatan dan penyebarluasan tersebut.

${ }_{55}^{5}$ Berdasarkan Undang-Undang Nomor 28 Tahun Tentang Hak Cipta

${ }^{56}$ Lihat pada Pasal 100 Undang-Undang Nomor 28 Tahun 2014 Tentang Hak Cipta, Bagian Kedua Tata Cara Gugatan

57 Lihat pada Pasal 101 Undang-Undang Nomor 28 Tahun 2014 Tentang Hak Cipta, Bagian Kedua Tata Cara Gugatan 
4) Putusan Pengadilan Niaga sebagaimana dimaksud pada ayat (3) harus disampaikan oleh juru sita kepada para pihak paling lama 14 (empat belas) Hari terhitung sejak putusan diucapkan.

Dengan berpegang pada ketentuan yang telah ada dalam peraturan perundang-undangan diatas, bahwa tidak ada proses atau prosedur yang berbeda dalam tata cara mengajukan gugatan pelanggaran Hak Cipta terkait ciptaan yang sudah dicatatkan ke DJHKI dan/ atau yang belum dicatatkan. Pelindungan Hak Cipta tidak menyaratkan pencatatan sebagai bukti atas lahirnya hak eksklusif pencipta terhadap ciptaannya. ${ }^{58}$ Perlindungan hukum bagi pemegang hak cipta atas pelanggaran Hak Cipta dibidang karya sinematografi dalam bentuk video Dance Challenge pada aplikasi TikTok dapat diselesaikan melalui Arbitrase atau Pengadilan Niaga. ${ }^{59}$

\section{PENUTUP}

\section{Kesimpulan}

Dari penjelasan di atas, maka dapat diambil kesimpulan bahwa pada saat akun aplikasi TikTok telah dibuat maka secara otomatis telah terjadi hubungan hukum antara pengguna (content creator) dengan Pihak TikTok dan dengan pemegang Hak Cipta yang tertuang dalam Konten Buatan Pengguna (User Generated Content).

Bahwa pengguna (content creator) yang membuat konten video Dance Challenge pada aplikasi TikTok sudah dipandang sebagai Pencipta dan sudah dilindungi sebagai pemegang Hak Cipta atas karya sinematografnya tersebut, dengan berpegang pada UU Hak Cipta sejak pertama kali dilakukan pengumuman karena perlindungan terhadap ciptaan tersebut lahir secara otomatis (automatically protection) sesuai pada Asas Deklaratif (first to file) setelah suatu ciptaan

${ }^{58}$ Yati Nurhayati, Pergeseran Delik Pelanggaran Hak Cipta Dalam Undang-Undang Hak Cipta Nomor 28 Tahun 2014, Penerbit Universitas Islam Kalimantan MAB, 2019. Hal. 13. Lihat juga Risa Amrikasari S.S., S.H., M.H., Gugatan Pelanggaran Hak Cipta Jika Ciptaan Belum Dicatatkan, Hukum Online, https://www.hukumonline.com/klinik/detail/lt5cd3b13c3b4be/gugatan-pelanggaran-hak-ciptajika-ciptaan-belum-dicatatkan (diakses pada tanggal 24 September 2020 pukul 10.44 WITA). Lihat juga Op.cit, Hal. 87

59 Hasrina Rahma, Yati Nurhayati, Legalitas Cover Song yang Diunggah ke Akun Youtube, 
diwujudkan dalam bentuk karya cipta nyata (expression work) bukan sekedar ide semata.

Bahwa pencatatan ciptaan video Dance Challenge pada aplikasi TikTok bukan sebagai syarat untuk mendapatkan Hak Cipta, melainkan hanya sebagai alat untuk mengukuhkan pembuktian dalam gugatan pelanggaran hak cipta kecuali terbukti sebaliknya sehingga jika terjadi peniruan atau penjiplakan karya cipta, si pencipta lebih mudah membuktikan haknya dan mengajukan tuntutan, karena ada bukti formal pencatatan.

Apabila konten video TikTok diunggah dengan maksud penggunaan secara komersial ke media sosial atau bahkan menjadi mata acara (program televisl) atau konten program di lembaga penyiaran, maka pelaku dapat dijerat dengan hukuman pidana yang telah diatur dalam UU Hak Cipta jika dilakukan tanpa hak dan/atau izin pencipta atau pemegang hak cipta. Tidak ada proses atau prosedur yang berbeda dalam tata cara mengajukan gugatan pelanggaran hak cipta terkait penciptaan video Dance Challenge pada aplikasi TikTok yang sudah dicatatkan DJHKI ataupun yang belum dicatatkan yang dapat diselesaikan melalui Arbitrase atau Pengadilan Niaga.

\section{Saran}

Sudah dipastikan bahwa aplikasi TikTok bisa menghibur diri pribadi dan orang lain bagi pengguna di seluruh dunia terutama di Indonesia, apalagi selama menjalani masa pandemi COVID-19. Tapi perlu diingat untuk semua, pergunakanlah aplikasi TikTok dengan bijak, karena saat ini sudah mulai banyak orang menggunakannya dengan hasil video yang mempermalukan diri mereka, membuat orang lain menjadi tidak nyaman (konten negatif) dan ada oknum yang menggunakan video Dance Challenge milik orang lain pada aplikasi TikTok untuk penggunaan secara komersial.

\section{DAFTAR PUSTAKA}

\section{Buku-Buku}

Hery Firmansyah, Perlindungan Hukum Terhadap Merek, Panduan Memahami Dasar Hukum Penggunaan dan Perlindungan Merek, (2011), Yogyakarta: Pustaka Yustisia. 
Isnaini, Yusran, Hak Cipta dan Tantangannya di Era Cyber Space, (2009), Bogor: Ghalia Indonesia.

M.Syamsudin, Operasional Penelitian Hukum, (2007), Jakarta: PT. Raja Grafindo Persada.

Muhamad Djumhana, Djubaedillah, Hak Milik Intelektual, Sejarah, Teori, dan Praktiknya di Indonesia, (2014), Bandung: PT. Citra Aditya Bakti.

Muhammad Djumhana, R. Djubaedillah, Hak Milik Intelektual Sejarah Teori dan Prakteknya di Indonesia, (1999), Bandung: Citra Aditya Bakti.

Mustika Zed, Metode Penelitian Kepustakaan, (2004), Jakarta: Yayasan Obor Nasional.

Ni Ketut Supasti Dharmawan, dkk, (2016), Hak Kekayaan Intelektual, Yogyakarta: Deepublish.

Peter Mahmud Marzuki, (2011), Penelitian Hukum, Jakarta: Kencana Prenada: Media Group.

Rachmadi Usman, Hukum Hak atas Kekayaan Intelektual, (2003), Bandung: PT. Alumni.

Satjipto Rahardjo, IImu Hukum, (2000), Cetakan ke-V, Bandung: Citra Aditya Bakti.

Soetandyo Wignjosoebroto dalam Sulistyowati Irianto dan Shidarta (ed.), (2017) Metode Penelitian Hukum; Konstelasi dan Refleksi, Jakarta: Yayasan Pustaka Obor Indonesia.

Yati Nurhayati, 2019, Pergeseran Delik Pelanggaran Hak Cipta Dalam UndangUndang Hak Cipta Nomor 28 Tahun 2014, Penerbit Universitas Islam Kalimantan MAB.

Yati Nurhayati, 2020, Pengantar IImu Hukum, Nusa Media, Bandung.

\section{Jurnal dan Hasil Penelitian}

Haryono, (2012), Perlindungan Hukum Terhadap Merk Terdaftar, Jurnal IImiah CIVIS, Volume II, Nomor 1.

Hasrina Rahma, Yati Nurhayati, (2020), Legalitas Cover Song yang Diunggah ke Akun Youtube, Jurnal Hukum Al-Adl, Volume XII, Nomor 1.

Lukas S. Ispandriarno, (2015), Membaca Media Daring, Mengikuti Media Sosial: Di Mana Etika?, Jurnal Komunikasi, Volume 10, Nomor 1.

Muchsin, (2003), Perlindungan dan Kepastian Hukum bagi Investor di Indonesia, Surakarta, Magister Ilmu Hukum Program Pascasarjana Universitas Sebelas Maret. 
Revian Tri Pamungkas, Djulaeka, (2019), Perlindungan Hukum Pemegang Hak Cipta Atas Lagu yang Diunggah Pada Aplikasi Tiktok, Simposium Hukum Indonesia, Volume 1, Nomor 1.

Setiono, (2004), Rule of Law (Supremasi Hukum), Magister Ilmu Hukum Program Pascasarjana Universitas Sebelas Maret, Surakarta.

Yati Nurhayati, Ifrani, \& M. Yasir Said, (2021), Metodologi Normatif dan Empiris Dalam Perspektif Ilmu Hukum, Jurnal Penegakan Hukum Indonesia, Vol. 2, No.1, Tahun 2021.

Yati Nurhayati, (2013), Perdebatan Antara Metode Normatif Dengan Metode Empirik Dalam Penelitian Ilmu Hukum Ditinjau Dari Karakter, Fungsi, dan Tujuan Ilmu Hukum, Jurnal A/ Adl, Vol 5, No 10.

Yati Nurhayati, Ifrani, Abdul Halim Barkatullah, dan M. Yasir Said, (2019), The Issue of Copyright Infringement in 4.0 Industrial Revolution: Indonesian Case, Jurnal Media Hukum, Vol. 26 No. 2.

Yati Nurhayati dan Ifrani, Judicial Review Of Shifted Offense in Copyright Law 28/2014, Jurnal Pembaharuan Hukum, Volume VI Nomor 3 SeptemberDesember 2019.

\section{Internet}

Abi Jam'an Kurnia, S.H., Jerat Pidana Re-Uploader Video di YouTube, Hukum Online, https://www.hukumonline.com/klinik/detail/ulasan/lt597f0045bbbe1/jeratpidana-ire-uploader-i-video-di-iyoutube

Adhitya Wibawa Putra, Tik Tok - Sosial Media Berbasis Video Yang Sedang Sangat Populer, Gadgetren, , https://gadgetren.com/2018/03/16/apa-itu-tik-tokvideo-media-sosial/

Andi Saputra, Mengenal Asas First to File yang Membuat Pierre Cardin Jatuh ke Orang Jakarta, detikNews, https://news.detik.com/berita/d3295968/mengenal-asas-first-to-file-yang-membuat-pierre-cardin-jatuhke-orang-jakarta

Anthony Ha, TikTok menambahkan reaksi video ke aplikasinya yang baru digabungkan (judul asli dalam bahasa Inggris "TikTok adds video reactions to its new/y-merged app"), Techcrunch, https://techcrunch.com/2018/09/03/tiktokreactions/\&usg=ALkJrhjd9PILMVWWvnGyHOgmg1IYcJfPEw

Audrey Homan, $Z$ is for Generation $Z$, Who are Generation $Z$ ?, Innovative Education in VT, dirilis pada tanggal 27 Oktober 2015, https://tiie.w3.uvm.edu/blog/who-are-generation-z/\#.X2_GIGgzbZb 
Author, Toutiao Parent Launches Global Competitor To Musical.Ly (dalam bahasa Inggris), TechNode, https://technode.com/2017/09/14/toutiao-backeddouyin-launches-competitor-to-musical-ly-tik-tok/

Bernadetha Aurelia Oktavira, S.H., Hukumnya 'Comot' Konten TikTok untuk Medsos atau Program TV, Hukum Online, https://www.hukumonline.com/klinik/detail/ulasan/lt5ece5f360135a/huku mnya-comot-konten-tiktok-untuk-medsos-atau-program-tv/

Brainly, https://brainly.co.id/tugas/15603735

Christina Liao, Cara membuat dan menemukan draf di TikTok menggunakan iPhone atau Android Anda (judul asli dalam bahasa Inggris "How to make and find drafts on TikTok using your iPhone or Android"), Business InsiderTech Reference, https://www.businessinsider.com/how-to-get-to-draftson-tiktok\%3Fr\%3DUS\%26IR\%3DT\&usg=ALkJrhhkw86I1ZWaxPupL_ho1PCSC9WUg

Himam Miladi, Belum Tahu Apa Itu TikTok? Berikut 10 Fakta Pentingnya, Kompasiana, https://www.kompasiana.com/primata/5e3624dad541df0711281812/belu $\mathrm{m}$-tahu-apa-itu-tiktok-berikut-10-fakta-pentingnya?page $=2$

Ifeng.com (dalam bahasa Tionghoa)，"抖音是否适合奢侈品牌？"， http://tech.ifeng.com/a/20180322/44916520_0.shtml

Kamus Besar Bahasa Indonesia (KBBI), Kamus versi online/ daring (dalam jaringan), https://kbbi.web.id/platform

Nabila Azarine, Mendunia, ini 7 "lagu tiktok" yang viral karena tren challenge!, Filemagz.com, https://www.filemagz.com/lagu-tiktok-yang-viral/

Redaksi Kumparan, Kem/u dan MA Luncurkan Rogatory Online Monitoring, kumparanNEWS, https://kumparan.com/kumparannews/kemlu-dan-maluncurkan-rogatory-online-monitoring/full

Risa Amrikasari S.S., S.H., M.H., Gugatan Pelanggaran Hak Cipta Jika Ciptaan Belum Dicatatkan, Hukum Online, https://www.hukumonline.com/klinik/detail/lt5cd3b13c3b4be/gugatanpelanggaran-hak-cipta-jika-ciptaan-belum-dicatatkan

Sam Byford, TikTok owner Bytedance is now the world's most valuable startup, The Verge, https://www.theverge.com/2018/10/26/18026250/bytedancechina-tiktok-valuation-highest-toutiao

Situs resmi TikTok, Ketentuan Umum - Seluruh Pengguna (terakhir diperbarui: Februari 2020), https://www.tiktok.com/legal/terms-of-use?lang=id

Situs resmi TikTok, Penegakan Hukum (terakhir diperbaharui: 13 Agustus 2020), https://www.tiktok.com/legal/law-enforcement?lang=id 
Sobih AW Adnan, Mengapa Tiktok Makin Digemari? Ini Alasan dan Dampaknya Secara Psikologis, Oase.id (Rubrik Inspirasi-Psikologi Remaja yang diampu oleh Muharini Aulia-Psikolog Remaja), https://m.oase.id/read//w4MP3mengapa-tiktok-makin-digemari-ini-alasan-dan-dampaknya-secarapsikologis

User, Ini Asal Muasal TikTok yang Kini Mendunia, Kumparan, https://kumparan.com/berita-hari-ini/ini-asal-muasal-tiktok-yang-kinimendunia-1ss18QadAEN/full

Wikipedia

bahasa

Indonesia,

Ensiklopedia

Bebas, https://id.wikipedia.org/wiki/Generasi_Z

Wikipedia, https://id.wikipedia.org/wiki/TikTok

\section{Peraturan Perundang-Undangan}

Undang-Undang Dasar Republik Indonesia Tahun 1945.

Kitab Undang-Undang Hukum Perdata; Burgelijk Wetboek voor Indonesie (BW).

Undang-Undang Nomor 21 Tahun 1961 Tentang Merek Perusahaan dan Merek Perniagaan.

Undang-Undang Nomor 19 Tahun 1992 Tentang Merek.

Undang-Undang Republik Indonesia No. 24 Tahun 2009 tentang Bendera, Bahasa dan Lambang Negara, serta Lagu Kebangsaan.

Undang-Undang Nomor 14 Tahun 2001 Tentang Paten.

Undang-Undang Nomor 15 Tahun 2001 Tentang Merek.

Undang-Undang Nomor 28 Tahun 2014 Tentang Hak Cipta. 